\title{
Pengaruh Kompensasi Terhadap Kinerja Karyawan
}

\author{
Alvi Nugraha ${ }^{1 *}$ dan Sri Surjani Tjahjawati ${ }^{2}$ \\ ${ }^{1}$ Jurusan Administrasi Niaga, Politeknik Negeri Bandung, Indonesia \\ 2 Jurusan Administrasi Niaga, Politeknik Negeri Bandung, Indonesia
}

\begin{abstract}
:
Compensation is an important thing that employees should be given to employees appropriately, whether compensated financially or non-financially compensated. Employees need compensation such as bonuses, benefits, a comfortable working environment, and work that can show the ability for employees to provide the best performance to the company. One of the objectives of this study is to determine the effect of financial compensation on employee performance in Cargill Tropical Palm (ISK Lake View Estate) of West Kalimantan. The sample in this research is all of Cargill Tropical Palm (ISK Lake View Estate) field employee as many as 110 people used as material of analysis. The concept of variable compensation consists of three dimensions including direct, indirect, and non-financial financial compensation. Performance variables consist of quality of work, quantity of work, reliability, knowledge, and cooperation. The analysis used is descriptive analysis. Test validity, reliability, classical assumptions, regression, correlation, and determination. The data obtained is processed using SPSS Statistics 20.0 program and yields the equation $Y=24.662$ $+0,543$, which means that with increasing compensation of 24,662 it will increase the employee performance of 0,543.
\end{abstract}

Keywords: compensation, employees performance

\begin{abstract}
Abstrak:
Kompensasi merupakan hal penting yang seharusnya diberikan perusahaan kepada karyawan secara layak, baik kompensasi finansial maupun kompensasi non finansial. Karyawan membutuhkan kompensasi seperti bonus, tunjangan, lingkungan kerja yang nyaman, dan pekerjaan yang dapat menunjukan kemampuan agar karyawan dapat memberikan kinerja terbaiknya kepada perusahaan. Salah satu tujuan dari penelitian ini adalah untuk mengetahui pengaruh kompensasi finansial terhadap kinerja karyawan di Cargill Tropical Palm (ISK Lake View Estate) Kalimantan Barat. Sampel pada penelitian ini adalah seluruh karyawan lapangan Cargill Tropical Palm (ISK Lake View Estate) sebanyak 110 orang yang digunakan sebagai bahan analisis. Konsep variabel kompensasi terdiri dari tiga dimensi diantaranya kompensasi finansial langsung, tidak langsung, dan non finansial. Variabel kinerja terdiri dari kualitas kerja, kuantitas kerja, keandalan, pengetahuan, dan kerja sama. Analisis yang digunakan adalah analisis deskriptif. Uji validitas, reliabilitas, asumsi klasik, regresi, korelasi, dan determinasi. Data yang didapat diolah menggunakan program SPSS Statistics 20.0 dan menghasilkan persamaan $\mathrm{Y}=24,662+0,543$, yang berarti dengan meningkatnya kompensasi sebesar 24,662 maka akan terjadi peningkatan pada kinerja karyawan sebesar 0,543.
\end{abstract}

Kata Kunci: kompensasi, kinerja karyawan

*Email korespondensi:

Alvi Nugraha

alvinugraha0711@gmail.com

\section{PENDAHULUAN}

Tanaman kelapa sawit berasal dari Africa Barat, tetapi kelapa sawit dapat tumbuh subur di Asia termasuk Indonesia. 
Kelapa sawit merupakan tanaman penghasil minyak nabati dan mempunyai nilai ekonomi yang tinggi. Selain menciptakan tenaga kerja yang baru, perkebunan kelapa sawit dapat mensejahterakan masyarakat menambah devisa Negara.

Produksi minyak sawit dunia didominasi oleh negara Indonesia dan Malaysia. Indonesia merupakan produsen dan eksportir minyak sawit terbesar di dunia menurut Priyambada (2016). Produksi kelapa sawit setiap tahun cenderung menongkat dikarenakan populasi yang meningkat dan kebutuhan akan produkproduk yang berasal dari minyak kelapa sawit. Indonesia dapat untuk mengembangkan kelapa sawit karena memiliki lahan subur yang luas dan sesuai untuk pertumbuhan kelapa sawit.

Penelitian yang dilakukan oleh Priyambada (2016), produksi kelapa sawit pada tahun 2008 mencapai 19.2 juta ton dan meningkat pada tahun 2016 yakni 32 juta ton. Ekspor kelapa sawit pada tahun 2008 mencapai 15.1 juta ton dan mengalami peningkatan pada tahun 2017 sebesar 27 juta ton. Data membuktikan bahwa perkembangan kelapa sawit di Indonesia sangat pesat serta industri perkebunan dan pengolahan sawit merupakan salah satu kunci bagi perekonomian Indonesia. Ekspor minyak kelapa sawit merupakan sumber devisa yang penting dan industri kelapa sawit telah memberikan kesempatan kerja bagi jutaan orang di Indonesia. Letak perkebunan kelapa sawit tersebar sekitar 70\% perkebunan sawit terletak di Sumatera dan $30 \%$ berada di Kalimantan. Dari data Sekertariat Pertanian Indonesia (2007), total luas perkebunan sawit di Indonesia pada tahun 2016 sekitar 8 juta hektar dan diprediksi akan meningkat menjadi 13 juta hektar pada tahun 2020.

Bisnis kelapa sawit merupakan salah satu bisnis yang dapat membantu perekonomian negara dan membantu meningkatkan kesejahteraan masyarakat. Perusahaan tentunya harus mensejahterakan anggota perusahaan seperti karyawan agar tetap nyaman dalam bekerja dan berkontribusi yang maksimal kepada perusahaan, Salah satu cara untuk mensejahterakan karyawan dengan memberikan kompensasi.

Kompensasi yang diberikan adalah kompensasi finansial dan kompensasi non finansial. Selain membutuhkan kompensasi finansial seperti bonus, insentif, tunjangan, asuransi dan lain-lain. Karyawan juga membutuhkan pekerjaan yang mampu memperlihatkan kemampuan mereka dan mendapatkan lingkungan kerja yang nyaman serta fasilitas yang dapat membantu menyelesaikan pekerjaan karyawan mendapatkan hasil yang maksimal.

Salah satu perusahaan perkebunan dan pengolahan kelapa sawit di Indonesia adalah Cargill Tropical Palm. Cargill merupakan perusahaan yang memproduksi minyak sawit, kernel dan minyak kernel. Perkebunan Cargill tersebar di Kalimantan dan Sumatera. PT Hindoli di Sumatera Selatan merupakan anak perusahaan pertama dari Cargill dalam perkebunan kelapa sawit di Indonesia yang diakuisisi pada tahun 1996, PT HSL dan PT ISK pada tahun 2005. Luas perkebunan sawit Cargill Tropical Palm berkisar 41.000 hectar serta memperkerjakan kurang lebih 10.000 orang karyawan

Karyawan di Cargill Tropical Palm memiliki prinsip kerja yang tinggi sehingga membuat perusahaan tersebut mengalami peningkatan produksi yang sangat pesat dan menjadi salah satu perusahaan kelapa sawit terbesar dalam segi pendapatan. Hal tersebut tidak lepas dari para karyawan yang memiliki kinerja yang baik, sehingga Cargill mengalami peningkatan jumlah panen yang signifikan.

Peningkatan hasil produksi tidak terlepas dari bantuan karyawan yang selalu memberikan kinerja terbaiknya untuk perusahaan. Peningkatan kesejahteraan dalam memacu kinerja yang lebih baik terus dilakukan oleh perusahaan. Selama ini, Cargill telah memberikan kompensasi finansial seperti bayaran pokok, bayaran 
insentif, bayaran diluar jam kerja (cuti), asuransi, rumah, dan kendaraan. Kompensasi non finansial yang diberikan berupa lingkungan kerja yang nyaman, dan aman.

Menurut Hasibuan (2009: 118), kompensasi merupakan semua pendapatan yang berbentuk uang, barang langsung atau tidak langsung yang diberikan perusahaan sebagai tanda jasa atas kontribusi kepada perusahaan. Menurut Sedarmayanti (2010: 239), kompensasi merupakan segala sesuatu yang diterima karyawan sebagai tanda jasa.

Tetapi pada bulan November 2016, sebagian karyawan melakukan demo dengan alasan kurang puas dengan kompensasi yang diberikan perusahaan berupa perhitungan gaji yang masih harian dan cash serta karyawan masih belum merasa puas dengan kompensasi dari perusahaan salah satunya karena listrik dirumah yang diberikan perusahaan hanya berfungsi hingga pukul 23:00 dan berfungsi lagi pukul 03:00 serta terdapat beberapa karyawan yang merasa kurang nyaman dengan sesama karyawan lainnya karena alasan yang tidak dapat disebutkan. Peristiwa demo tersebut menyebabkan menurunnya kinerja karyawan dan menyebabkan beberapa karyawan berhenti dari pekerjaannya

\section{TINJAUAN PUSTAKA Kompensasi}

Dalam perusahaan, karyawan merupakan bagian yang sangat penting dalam mencapai tujuan. Setiap karyawan tentunya memiliki banyak perbedaan dalam keahlian, kemampuan, kebutuhan dan jenis kelamin. Salah satu bentuk achievement / penghargaan yang diberikan perusahaan atas kinerja dari karyawan adalah kompensasi. Dengan diberikannya penghargaan dan pengakuan, karyawan akan memberikan kinerja terbaiknya sebagai timbal balik atas penghargaan yang diberikan oleh perusahaan juga untuk mempertahankan dan memelihara semangat kerja serta motivasi para pegawai.
Menurut Marwansyah (2010: 269) kompensasi merupakan imbalan yang perusahaan berikan kepada para karyawan atas kinerja yang diberikan terhadap organisasi baik imbalan langsung maupun tidak langsung, finansial maupun nonfinansial. Menurut Hasibuan (2009: 118) kompensasi merupakan pendapatan yang berbentuk uang atau barang yang diberikan perusahaan kepada karyawan atas jasa yang diberikan. Tanpa kompensasi yang memadai, pegawai yang ada sekarang cenderung keluar dari organisasi yang berakibat organisasi mengalami kesulitan dalam replacement, terlebih dalam recruiting. Menurut Suparyadi (2014: 271) kompensasi adalah keseluruhan pendapatan yang diberikan kepada karyawan sebagai penghargaan atas kontribusi yang diberikannya kepada organisasi, baik bersifat finansial maupun nonfinansial. Kesimpulannya kompensasi adalah imbalan yang diberikan perusahaan atas kinerja yang diberikan, baik kompensasi finansial dan non finansial

Jenis-jenis dari kompensasi menurut Sedarmayanti (2016: 241-243):

1. Kompensasi Tidak Langsung Jaminan merupakan kompensasi tidak langsung dikarenakan jaminan biasanya tidak berkaitan dengan prestasi kerja.
a. Jaminan asuransi
b. Jaminan keamanan pegawai
c. Jaminan cuti
d. Jaminan kafetaria: Jam kerja sesuai

2. Kompensasi Pelengkap

Kompensasi pelengkap biasanya tidak langsung berkaitan dengan kinerja karyawan. Kompensasi pelengkap dianggap penting karena dapat mempengaruhi sikap dari karyawan, tuntutan perserikatan karyawan, persaingan dalam organisasi dan merupakan aturan pemerintah

Sedangkan menurut Mondy dan Noe dalam Marwansyah (2010: 276), kompensasi terdiri dari:

1. Kompensasi Finansial

a. Kompensasi Langsung 
1) Gaji pokok dan upah

2) Bayaran atas Prestasi

3) Bayaran Insentif, seperti bonus

b. Kompensasi Tidak Langsung

1) Program asuransi kesehatan, jiwa, dan kecelakaan

2) Bayaran diluar jam kerja seperti hari besar, cuti tahunan dan cuti hamil

3) Fasilitas (rumah karyawan, kendaraan, air, listrik, klinik, tempat ibadah)

2. Kompensasi Non-finansial

a. Pekerjaan seperti pekerjaan yang mempunyai tantangan, dan pengakuan atas hasil kerja

b. Lingkungan kerja seperti rekan kerja baik dan menyenangkan serta mendapatkan lingkungan kerja yang nyaman

Menurut Ambar Teguh (2009: 267)

teori keadilan (equity theory) harus diciptakan. Teori keadilan (equity theory) harus diadakan dalam organisasi karena penting bagi karyawan. Ketidakadilan bukan merupakan kepuasan pegawai. Dengan kompensasi yang adil, dapat meningkatkan motivasi pegawai. kompensasi yang adil adalah jika karyawan tersebut merasa bahwa kompensasi yang diberikan benar-benar adil.

\section{Kinerja}

Salah satu yang menentukan berhasil atau tidaknya perusahaan ditentukan oleh kinerja karyawannya. Jika kinerja karyawannya baik, maka perusahaan dapat mencapai tujuannya dengan lebih cepat, tetapi jika kinerja karyawannya buruk maka yang terjadi adalah sebaliknya. Dengan demikian, perusahaan harus meningkatkan dan mempertahankan kinerja karyawannya.

Menurut Marwansyah (2010: 229) kinerja merupakan pencapaian atau prestasi seseorang yang berkenaan dengan tugastugas yang dibebankan kepadanya. Menurut Gani (2009: 221), kinerja adalah hasil dari pelaksanaan pekerjaan karyawan kepada organisasi dimana ia bekerja sebagai karyawan. Kinerja merupakan hasil yang diperoleh oleh suatu organisasi baik organisasi tersebut bersifat profit oriented atau non profit oriented yang dihasilkan selama satu periode waktu dan kinerja merupakan gambaran mengenai tingkat pencapaian suatu kegiatan dalam mewujudkan misi dan visi perusahaan yang tertuang dalam perencanaan strategis perusahaan dan kinerja dalam organisasi dianggap sebagai efektivitas organisasi secara menyeluruh untuk memenuhi kebutuhan yang ditetapkan dari kelompok yang berkaitan dengan peningkatan kemampuan (Fahmi, 2015: 2)

Menurut Sukmawati (2008: 179), kinerja adalah mempengaruhi seberapa banyak seseorang memberikan kontribusi kepada organisasi antara lain termasuk kuantitas output, kualitas output, jangka waktu output, kehadiran di tempat kerja, dan sikap kooperatif dan tingkat prestasi seseorang dalam suatu organisasi yang dapat meningkatkan produktivitas

Menurut Kaswan (2015: 156) faktorfaktor yang mempengaruhi kinerja diantaranya motivasi, etika kerja, desain pekerjaan, rekan kerja dan dukungan dari organisasi yang mencakup pelatihan dan pengembangan. Menurut Ivancevich dalam Juni (2015:270) faktor-faktor yang dapat mempengaruhi kinerja adalah variabel individu seperti mental, pengalaman dan latar belakang, variabel psikologi seperti sikap dan prilaku, maupun variabel organisasi seperti jenis pekerjaan dan gaya kepemimpinan

Kinerja karyawan diukur sesuai standar dari organisasi tersebut. Mondy \& Noe dalam Juni (2015: 271) menyatakan pengukuran kinerja dapat dilihat dan dilakukan dengan beberapa dimensi yaitu:

1. Kualitas Pekerjaan (Quantity of Work)

2. Kualitas Pekerjaan (Quality of Work)

3. Kemandirian (Dependability)

4. Inisiatif (Initiative)

5. Adaptabilitas (Adaptability)

Sedangkan menurut Idham \& Subowo (2005: 135) dimensi untuk mengukur kinerja adalah: 
1. Kualitas kerja, meliputi ketelitian, kerapihan, ketepatan dan keterampilan kerja

2. Kuantitas kerja, meliputi kemampuan dalam menghasilkan volume atas pekerjaan-pekerjaan baru

3. Pengetahuan, berhubungan dengan pengetahuan individu dalam pekerjaannya

4. Keandalan, berhubungan dengan kemampuan individu dalam melaksanakan tugasnya

5. Kerja sama, meliputi kemampuan menyelesaikan tugas bersama-sama

\section{Hubungan Kompensasi dengan Kinerja Karyawan}

Bagi perusahaan, karyawan merupakan SDM yang sangat penting untuk mencapai tujuan perusahaan. Pemberian kompensasi kepada karyawan merupakan bentuk balas jasa yang diberikan perusahaan atas kinerja yang telah karyawan berikan. Jika kompensasi dalam perusahaan dianggap layak oleh karyawan, hal tersebut dapat berpengaruh terhadap kinerja dan loyalitas karyawan. Kebanyakan demo kerja yang dilakukan disebabkan karena ketidakpuasan akan upah yang diberikan

Pembayaran kompensasi pada umumnya diberikan berdasarkan prestasi dan kemampuan, tetapi jika karyawan yang kurang memiliki prestasi dan kemampuan akan merasa tertekan. Oleh karena itu, pemberian kompensasi dapat sesuai dengan kebutuhan karyawan tersebut. Henderson dalam Aamir (2012: 4) mengatakan:

"The productivity of an organization and human resource management has a direct relationship with each other. If employees are managed appropriately i.e. job analysis, recruitment, training, motivational tools like compensation"

Produktivitas organisasi dan manajemen sumber daya manusia memiliki hubungan langsung dengan satu sama lain. Jika karyawan dikelola dengan tepat yaitu analisis pekerjaan, rekrutmen, pelatihan, alat motivasi seperti kompensasi. Jadi kompensasi merupakan salah satu cara agar meningkatkan motivasi karyawan dalam meningkatkan kinerjanya.

Kompensasi yang diberikan harus diberikan secara adil dan tidak jauh dari harapan karyawan. Jika hal tersebut dapat terpenuhi maka kepuasan dari karyawan dapat menjadi pemicu untuk dapat meningkatkan kinerja. Jika pemberian kompensasi tidak tepat waktu berakibat pada kedisiplinan, sikap dan semangat kerja karyawan menurun (Suwati, 2013: 51)

Kompensasi, motivasi, dan kinerja merupakan unsur yang sangat penting dalam suatu proses manajemen sumber daya manusia. Kinerja karyawan yang nampak dalam output yang dihasilkannya merupakan pencerminan dari seberapa besar atau kuat kompensasi dan motivasi yang dimiliki oleh orang tersebut (Suparyadi, 2014: 293)

Salah satu fungsi kompensai yaitu dapat menajdi faktor motivasi untuk karyawan agar bekerja lebih baik. Untuk memperoleh kompensasi yang baik dan diharapkan maka karyawan akan bekerja lebih baik (Yuniarsih, 2009: 127). Kesimpulannya bahwa kompensasi yang diberikan kepada karyawan berhubungan dan memiliki pengaruh positif terhadap kinerja karyawan

\section{METODE PENELITIAN}

Jenis penelitian ini merupakan jenis penelitian kualitatif yaitu data adalah bahan mentah yang perlu diolah kembali sehingga menghasilkan informasi atau keterangan, baik data kualitatif maupun data kuantitatif yang menunjukkan fakta (Riduwan, 2010: 5). Populasi dari penelitian ini adalah karyawan lapangan yang menerima kompensasi di Cargill Tropical Palm (ISK Lake View Estate) yang berjumlah 150 orang. Dikarenakan jumlah populasi yang akan diteliti sudah diketahui jumlah pastinya menurut Slovin dan Suwati (2013: 44) sampelnya dihitung menggunakan rumus:

$\mathrm{n}_{\mathrm{b}}=\frac{\mathrm{N}}{\mathrm{N} \cdot \mathrm{D}^{2}+1}$ 
Keterangan :

$\mathrm{n}$ = Jumlah Sampel

$\mathrm{N}=$ Jumlah Populasi (150 orang)

$\mathrm{D}^{2}=$ Presisi (ditetapkan 5\% dengan tingkat kepercayaan 95\%)

Sehingga dipeoleh angka sampel 109.090909 (dibulatkan menjadi 110) untuk populasi sebesar 150 .

Tabel 1 Jenis Kelamin Responden

\begin{tabular}{|l|c|c|c|c|}
\hline & $\begin{array}{c}\text { Freque } \\
\text { ncy }\end{array}$ & Percent & $\begin{array}{c}\text { Valid } \\
\text { Percent }\end{array}$ & $\begin{array}{c}\text { Cumulative } \\
\text { Percent }\end{array}$ \\
\hline Laki-laki & 83 & 75.5 & 75.5 & 75.5 \\
\hline Perempuan & 27 & 24.5 & 24.5 & 100.0 \\
\hline Total & 110 & 100.0 & 100.0 & \\
\hline
\end{tabular}

Sumber: Hasil pengolahan data (2017)

Tabel 2 Usia Responden

\begin{tabular}{|l|c|c|c|c|}
\hline & $\begin{array}{c}\text { Frequen } \\
\text { cy }\end{array}$ & Percent & $\begin{array}{c}\text { Valid } \\
\text { Percent }\end{array}$ & $\begin{array}{c}\text { Cumulative } \\
\text { Percent }\end{array}$ \\
\hline$<20$ Tahun & 14 & 12.7 & 12.7 & 12.7 \\
\hline$>50$ Tahun & 3 & 2.7 & 2.7 & 15.5 \\
\hline 21-30 Tahun & 33 & 30.0 & 30.0 & 45.5 \\
\hline 31-40 Tahun & 43 & 39.1 & 39.1 & 84.5 \\
\hline 41-50 Tahun & 17 & 15.5 & 15.5 & 100.0 \\
\hline Total & 110 & 100.0 & 100.0 & \\
\hline
\end{tabular}

Sumber: Hasil pengolahan data (2017)

Tabel 3 Pendidikan Terakhir Responden

\begin{tabular}{|l|c|c|c|c|}
\hline & $\begin{array}{c}\text { Frequen } \\
\text { cy }\end{array}$ & Percent & $\begin{array}{c}\text { Valid } \\
\text { Percent }\end{array}$ & $\begin{array}{c}\text { Cumulative } \\
\text { Percent }\end{array}$ \\
\hline SD & 64 & 58.2 & 58.2 & 58.2 \\
\hline SMA/SMK & 6 & 5.5 & 5.5 & 63.6 \\
\hline SMP & 27 & 24.5 & 24.5 & 88.2 \\
\hline STRATA 1 & 2 & 1.8 & 1.8 & 90.0 \\
\hline $\begin{array}{l}\text { Tidak } \\
\text { Sekolah }\end{array}$ & 11 & 10.0 & 10.0 & 100.0 \\
\hline Total & 110 & 100.0 & 100.0 & \\
\hline Sumber
\end{tabular}

Sumber: Hasil pengolahan data (2017)

Sumber: Hasil pengolahan data (2017)

\section{HASIL DAN PEMBAHASAN Identitas Responden}

Hasil dari identifikasi pada Tabel 1 menunjukan bahwa jumlah responden lakilaki lebih banyak $(75,5 \%)$ dibandingkan jumlah responden perempuan $(24,5 \%)$. Hal ini terjadi karena beban kerja di perkebunan kelapa sawit cukup berat sehingga mengakibatkan penarikan tenaga kerja berjenis kelamin laki-laki lebih diutamakan.

Pada Tabel 2, dari kelima kelompok umur yang ada, ada 3 orang yang diatas 50 tahun. Mayoritas dari responden memiliki umur antara 20 - 40 tahun. Dengan kata lain, Cargill Tropical Palm (ISK Lake View Estate) memiliki mayoritas karyawan yang berada pada usia kerja dan produktif mengingat beban kerja karyawan harus sesuai dengan pengalaman dan pengetahuan pada setiap bidangnya.

Untuk identifikasi berdasarkan pendidikan terakhir, responden terbagi ke dalam 7 kategori kelompok. Mayoritas dari responden memiliki pendidikan terakhir sekolah dasar $(58,2 \%)$. Hal ini disebabkan perusahaan tidak mencari seseorang yang mempunyai pendidikan tinggi untuk ditempatkan di lapangan, karena skill utama yang harus dimiliki karyawan lapangan di perusahaan adalah fisik yang kuat dan rajin.

Hasil dalam Tabel 4 menunjukan bahwa responden memiliki pendapatan diatas tiga juta rupiah sebanyak $69,1 \%$ dan $30,9 \%$ memiliki penghasilan antara dua sampai tiga juga rupiah. Hal ini menandakan bahwa perusahaan tidak memberikan salary berdasarkan tingkat pendidikan responden dan tetap memberikan gaji diatas UMR (upah minimum regional).

Berdasarkan hasil uji validitas kompensasi, dapat diketahui bahwa pada variabel kompensasi yang sudah diuji dinyatakan valid karena seluruh nilai yang ada dalam kolom Corrected Item - Total Correlation seluruhnya lebih besar dari 0,30

Tabel 4 Pendapatan per Bulan

\begin{tabular}{|l|c|c|c|c|}
\hline & $\begin{array}{c}\text { Frequen } \\
\text { cy }\end{array}$ & Percent & $\begin{array}{c}\text { Valid } \\
\text { Percent }\end{array}$ & $\begin{array}{c}\text { Cumulative } \\
\text { Percent }\end{array}$ \\
\hline$>3.000 .001$ & 76 & 69.1 & 69.1 & 69.1 \\
\hline $\begin{array}{l}2.000 .001- \\
3.000 .000\end{array}$ & 34 & 30.9 & 30.9 & 100.0 \\
\hline Total & 110 & 100.0 & 100.0 & \\
\hline
\end{tabular}

dinyatakan reliabel karena lebih besar dari 
0,60. Sehingga dapat disimpulkan bahwa indikator-indikator variabel kompensasi valid dan memiliki kehandalan yang cukup tinggi.

Berdasarkan hasil kolom Corrected Item - Total Correlation dapat dikatakan bahwa indikator kinerja memiliki validitas yang tinggi karena semuanya lebih dari 0,30, kemudian kolom Cronbach's Alpha variabel kinerja bernilai 0,851 lebih besar dari 0,60. Dari hasil pengujian diatas dapat diambil kesimpulan bahwa variabel kinerja memiliki validitas tinggi dan juga reliabel.

Tabel 5 Hasil Analisis Deskriptif Variabel Kompensasi

\begin{tabular}{|c|c|c|c|c|}
\hline & Min & Maks & Mean & SD \\
\hline Kompensasi & 2.00 & 5.00 & 3.6474 & 0.8907 \\
\hline
\end{tabular}

Sumber: Hasil pengolahan data (2017)

Dari Tabel 5, terlihat bahwa rata-rata dari variabel kompensasi adalah sebesar 3,64 , hasil tersebut masuk ke dalam interval tinggi/besar yaitu 3,41 - 4,20 dan Kemudian standar deviasi menunjukan angka 3.6474 atau sama dengan $24.49 \%$ dari nilai mean. Hasil tersebut dapat disimpulkan bahwa kompensasi yang diberikan oleh Cargill Tropical Palm (ISK Lake View Estate) kepada karyawan lapangan sudah besar sehingga kompensasi finansial langsung, tidak langsung dan kompensasi non finansial yang diberikan sudah sesuai dengan apa yang diinginkan oleh karyawan, Kompensasi yang lebih baik akan menciptakan kepuasan kepada karyawan dan akan memotivasi karyawan untuk bekerja lebih baik serta kompensasi berfungsi sebagai faktor motivasi dalam meningkatkan kinerja dan produktivitas kerja karyawan (Yuniarsih, 2009: 127)

Tabel 6 Hasil Analisis Deskriptif Kinerja Karyawan

\begin{tabular}{|l|l|l|l|l|}
\hline & Min & Maks & Mean & SD \\
\hline $\begin{array}{l}\text { Kinerja } \\
\text { Karyawan }\end{array}$ & 3.00 & 5.00 & 3.6678 & 0.9840 \\
\hline
\end{tabular}

Sumber: Hasil pengolahan data (2017)
Tabel 6 menunjukan bahwa kinerja yang dimiliki oleh responden bernilai tinggi dengan nilai rata-rata mean 3.66. Karena nilai rata-rata berada pada interval antara 3,41 - 4,20 maka dapat disimpulkan bahwa karyawan Cargill Tropical Palm (ISK Lake View Estate) memiliki kualitas kerja, kuantitas kerja, pengetahuan, keandalan, dan kerjasama yang tinggi/besar sehinga karyawan Cargill Tropical Palm (ISK Lake View Estate) dapat menghasilkan pekerjaan yang baik dan dapat menguntungkan perusahaan. Standar deviasi yang dimiliki variabel kinerja sebesar 0.98 yang berarti 26,88\% dari mean.

Tabel 7 Hasil Analisis Korelasi Kompensasi Terhadap Kinerja

\begin{tabular}{|l|l|l|l|}
\hline \multirow{4}{*}{ Kompensasi } & & Kompensasi & Kinerja \\
\cline { 2 - 4 } & Pearson Correlation & 1 & $.601^{* *}$ \\
\cline { 2 - 4 } & Sig. (2-tailed) & & .000 \\
\cline { 2 - 4 } & $\mathrm{N}$ & 110 & 110 \\
\hline \multirow{3}{*}{ Kinerja } & Pearson Correlation & $.601^{* *}$ & 1 \\
\cline { 2 - 4 } & Sig. (2-tailed) & .000 & \\
\cline { 2 - 4 } & $\mathrm{N}$ & 110 & 110 \\
\hline
\end{tabular}

**. Correlation is significant at the 0.01 level (2-tailed).

Sumber: Hasil pengolahan data (2017)

Tabel 8 Hasil Analisis Regresi Sederhana Kompensasi (X) Terhadap Kinerja (Y)

\begin{tabular}{|c|c|c|c|c|c|}
\hline \multirow{2}{*}{ Model } & \multicolumn{2}{|c|}{$\begin{array}{c}\text { Unstandardi } \\
\text { zed } \\
\text { Coefficients }\end{array}$} & $\begin{array}{c}\text { Standardized } \\
\text { Coefficients }\end{array}$ & \multirow{2}{*}{$\mathrm{t}$} & \multirow{2}{*}{ Sig. } \\
\cline { 2 - 5 } & $\mathrm{B}$ & $\begin{array}{c}\text { Std. } \\
\text { Error }\end{array}$ & Beta & & \\
\hline (Constant) & 24.66 & $\begin{array}{l}3.67 \\
7\end{array}$ & & 6.707 & .000 \\
\hline Kompensasi & .543 & .070 & .601 & 7.809 & .000 \\
\hline
\end{tabular}

Sumber: Hasil pengolahan data (2017)

Hasil analisis korelasi antara kompensasi dan kinerja yang dapat dilihat pada Tabel 7 menunjukan bahwa variabel kompensasi dengan kinerja berkorelasi dan signifikan. Korelasi yang dihasilkan kuat karena bernilai 0,601 (berada pada interval $0,60-0,799)$ dengan tingkat signifikansi sempurna karena Sig 0,000. Hal ini dapat 
dinyatakan bahwa ketika perusahaan menambah kompensasi maka pada saat yang bersamaan terjadi peningkatan kinerja.

Hasil regresi dapat dilihat pada Tabel 8 untuk nilai (a) constant/konstanta bernilai 24, 662 dengan koefisien regresi (b) sebesar 0,543. Dari hasil tersebut dapat diperoleh persamaan regresi yaitu:

$\mathbf{Y}=\mathbf{a}+\mathbf{b X}$

$Y=24,662+0,543$

Hal ini menunjukan bahwa jika kompensasi bertambah satu angka, maka kinerja karyawan akan meningkat sebesar 0,543. Hal ini menunjukan bahwa kompensasi berpengaruh positif terhadap kinerja di Cargill Tropical Palm (ISK Lake View Estate) Kalimantan Barat. Tingkat signifikansi dari tabel sebesar 0,000 (lebih kecil dari 0,05) yang berarti terdapat pengaruh yang signifikan antara kompensasi terhadap kinerja. Dapat disimpulkan bahwa $\mathrm{H}_{0}$ ditolak dan $\mathrm{H}_{1}$ diterima.

Pada Tabel 8 nilai $\mathrm{t}$ hitung untuk variabel ini lebih besar dari t hitung yaitu $\mathrm{t}$ hitung (7.809) > t tabel 1.981 dan nilai signifikansi $(0,000<0,05)$ artinya variabel kompensasi (X) berpengaruh positif dan signifikan terhadap kinerja karyawan di Cargill Tropical Palm (ISK Lake View Estate).

Tabel 9 Hasil Analisis Uji F

\begin{tabular}{|l|l|c|c|c|c|c|}
\hline \multicolumn{2}{|l|}{ Model } & $\begin{array}{c}\text { Sum of } \\
\text { Squares }\end{array}$ & df & $\begin{array}{c}\text { Mean } \\
\text { Square }\end{array}$ & F & Sig. \\
\hline \multirow{2}{*}{1} & Regression & 2462.201 & 1 & 2462.201 & 60.977 & $.000^{\mathrm{a}}$ \\
\cline { 2 - 8 } & Residual & 4360.929 & 108 & 40.379 & & \\
\cline { 2 - 8 } & Total & 6823.130 & 109 & & & \\
\hline
\end{tabular}

Sumber: Hasil pengolahan data SPSS 16.0 (2017)

Berdasarkan Tabel 9 ditunjukan bahwa $F_{\text {hitung }}$ sebesar 60.977, sedangkan hasil $F_{\text {tabel }}$ pada tabel distribusi dengan tingkat kesalahan $5 \%$ adalah 3,93. Hal ini berarti $F_{\text {hitung }}>F_{\text {tabel }}(60.977>3,93)$. Nilai signifikansi lebih kecil dari 0,1. Hasil tersebut menunjukan bahwa $\mathrm{H} 0$ ditolak dan H1 diterima. Dengan arah koefisien positif. Dengan demikian diperoleh bahwa hipotesis
Terdapat pengaruh yang signifikan dan positif antara kompensasi dengan kinerja karyawan.

\section{KESIMPULAN}

Berdasarkan penelitian yang telah dilakukan, diperoleh kesimpulan sebagai berikut:

1. Kompensasi yang diberikan kepada karyawan lapangan Cargill Tropical Palm (ISK Lake View Estate) secara keseluruhan sudah besar karena bernilai 3,64 dan berada pada interval tinggi/besar yaitu 3,41 - 4,20. Hasil tersebut dapat disimpulkan bahwa kompensasi yang diberikan oleh Cargill Tropical Palm (ISK Lake View Estate) kepada karyawan lapangan sudah besar sehingga kompensasi finansial langsung, tidak langsung dan kompensasi non finansial yang diberikan sudah sesuai dengan apa yang diinginkan oleh karyawan.

2. Secara keseluruhan kinerja karyawan lapangan Cargill Tropical Palm (ISK Lake View Estate) termasuk dalam kategori tinggi/besar karena 3,66 dan termasuk dalam interval 3,41 - 4,20. Tabel 6 menunjukan bahwa kinerja yang dimiliki oleh responden bernilai tinggi dengan nilai rata-rata mean 3.66. Karena nilai rata-rata berada pada interval antara 3,41 - 4,20 maka dapat disimpulkan bahwa karyawan Cargill Tropical Palm (ISK Lake View Estate) memiliki kualitas kerja, kuantitas kerja, pengetahuan, keandalan, dan kerjasama yang tinggi/besar sehinga karyawan Cargill Tropical Palm (ISK Lake View Estate) dapat menghasilkan pekerjaan yang baik dan dapat menguntungkan perusahaan.

\section{Saran}

Berdasarkan hasil penelitian pada variabel kompensasi berada pada interval besar/tinggi, ada beberapa hal yang direkomendasikan pada perusahaan terkait dengan dimensi kompensasi seperti 
kenaikan gaji menyusul kebutuhan karyawan yang semakin bertambah dan juga resiko di lapangan yang besar dan membutuhkan tenaga yang besar juga.

Untuk meningkatkan kinerja. Sebaiknya komunikasi antara karyawan juga harus diperhatian oleh atasan karena menurut peneliti sendiri masih terdapat rasisme yang terjadi pada karyawan Kompensasi mempunyai peranan penting dalam meningkatkan kinerja karyawan. Pekerjaan dan lingkungan yang kurang nyaman akan mempengaruhi kinerja karyawan dalam sebuah perusahaan. diharapkan perusahaan dapat memperbaiki masalah-masalah terkait dengan kompensasi terutama dalam hal fasilitas perusahaan dan pengembangan kompensasi

\section{DAFTAR PUSTAKA}

Aamir, A. (2012). Compensation Methods and Employees' Motivation (With Reference to Employees of National Commarcial Bank Riyadh), International Journal of Human Resource Studies, Volume 2 nomor 3. 221-228.

Ambar, T. (2009). Manajemen Sumber Daya Manusia. Yogyakarta: Graha Ilmu.

Fahmi, I. (2015). Manajemen Kinerja (Teori dan Aplikasi). Bandung: Alfabeta.

Gani. A. (2009). Analisis Faktor-Faktor yang Mempengaruhi Kinerja Pegawai Kantor PBB, Jurnal Aplikasi Manajemen, Vol.7 No.1, Universitas Muslim Indonesia (UMI), Makasar.

Hasibuan, M. (2009). Manajemen Sumber Daya Manusia. Jakarta: PT Bumi Aksara.

Idham, E., \& Subowo. (2005). Pengaruh Kepemimpinan, Lingkungan Kerja Fisik, dan Kompensasi terhadap Kinerja Karyawan di PT. Pertamina (Persero). Diunduh tanggal 13 Februari 2017

Juni, D. (2015). Perencanaan dan Pengembangan Sumber Daya Manusia. Bandung: Alfabeta

Kaswan. (2015). Pengembangan Sumber Daya Manusia Dari Konsepsi,
Paradigma, dan Fungsi sampai Aplikasinya. Bandung: Alfabeta

Marwansyah. (2010). Manajemen Sumber Daya Manusia. Bandung: Alfabeta.

Mondy, R. W., \& Noe, R. M. (2005). Human Resource Management. Ninth Edition. USA: Prentice Hall

Priyambada, R., \& Winardi, W. Minyak Kelapa Sawit. 2 Februari 2016 http://www.indonesia-

investments.com/id/bisnis/komoditas/mi nyak-sawit/item166. Diunduh tanggal 10 September 2016

Riduwan. (2010). Skala Pengukuran Variabel-Variabel Penelitian. Bandung: Alfabeta

Sedarmayanti. (2010). Manajemen Sumber Daya Manusia Reformasi BIrokrasi dan Manajemen Pegawai Negeri Sipil. Bandung: Refika Aditama

Sedarmayanti. (2016). Manajemen Sumber Daya Manusia Reformasi BIrokrasi dan Manajemen Pegawai Negeri Sipil Edisi Revisi. Bandung: Refika Aditama

Sekretariat, Jenderal, Pertanian. (2007). Journal Gambaran Sekilas Industri Minyak Kelapa Sawit. Diunduh tanggal 12 September 2016

Sukmawati, F. (2008). Pengaruh Kepemimpinan, Lingkungan Kerja Fisik, dan Kompensasi terhadap Kinerja Karyawan di PT Pertamina (Persero) UMPS III Terminal Transit Utama Balongan, Indramayu. Jurnal Ekonomi dan Bisnis, 175-194

Suparyadi. (2014). Manajemen Sumber Daya Manusia - Menciptakan Keunggulan Bersaing Berbasis Kompetensi SDM. Yogyakarta: Andi

Suwati, Y. (2013). Pengaruh Kompensasi dan Motivasi Kerja Terhadap Kinerja Karyawan pada PT Tunas Hijau Samarinda. Journal Ilmu Administrasi Bisnis, 41-55

Yuniarsih, P. D., \& Suwatno, M. (2009). Manejemen Sumber Daya Manusia Teori, Aplikasi, dan Isu Penelitian. Bandung: Alfabeta. 